\title{
ORIENTASI PASAR PADA UD. BINTANG LIMA PRODUK KACANG TELUR DI KOTA TOMOHON
}

\author{
Steriany Maria Tulenan \\ Leonardus R. Rengkung \\ Joachim N.K. Dumais
}

\begin{abstract}
The objective of this research is to determine the orientation of the market (customer orientation, competitor orientation and coordination between functions). This research conducted for three months, since February to April 2016. The data used in this research is the primary data taken using a survey method using a questionnaire that by distributing questionnaires to employees and manager. A questionnaire was used to determine the customer orientation, competitor orientation and coordination between functions. Based on the results of research conducted at the Five Star UD, it can be concluded that Five Star has captured the market orientation that is good with market orientation value of 64.31 persent. UD's market orientation on customer orientation is said to be good in that understanding of these UD on the wishes of customers, know what customers want, satisfaction and create value for customers. In the competitor orientation, this UD could respond to acts of competitors, competitive advantage to seize opportunities, and try to improve and find a strategy to fight its competitors. While in the coordination between functions, workers has contributed to the strategy of Five Star UD and the customer value creation, mutual cooperation among workers, and has understood the needs of customers so as to create satisfaction for its customers.
\end{abstract}

Key words: the orientation of the market, egg peanut, Tomohon City,

\section{ABSTRAK}

Penelitian ini bertujuan untuk mengetahui orientasi pasar (orientasi pelanggan, orientasi pesaing dan koordinasi antar fungsi). Penelitian ini dilaksanakan selama tiga bulan sejak bulan Februari sampai bulan April 2016. Data yang digunakan dalam penelitian ini adalah data primer yaitu data yang diambil dengan menggunakan metode survey serta menggunakan kuesioner yaitu dengan menyebarkan kuesioner pada karyawan-karyawan dan pimpinan perusahaan. Kuesioner digunakan untuk mengetahui orientasi pada pelanggan, orientasi pada pesaing dan koordinasi antar fungsi. Berdasarkan hasil penelitian yang dilaksanakan di UD Bintang Lima, dapat disimpulkan bahwa UD Bintang Lima telah menangkap orientasi pasar yaitu Baik dengan nilai orientasi pasarnya 64,31 persen. Orientasi pasar pada UD ini dikatakan baik dalam orientasi pelanggan yaitu pemahaman UD ini terhadap keinginan pelanggan, mengetahui apa yang diinginkan pelanggan, kepuasan serta menciptakan nilai bagi pelanggan. Dalam orientasi pesaing, UD ini merespon tindakan pesaing, menangkap peluang keunggulan bersaing, dan berusaha meningkatkan dan menemukan strategi untuk melawan pesaingnya. Sedangkan dalam koordinasi antar fungsi, para pekerja telah berkontribusi pada strategi UD Bintang Lima dan pada penciptaan nilai pelanggan, saling bekerjasama antar pekerja, dan telah memahami kebutuhan pelanggan sehingga tercipta kepuasan bagi pelanggannya.

Kata kunci: orientasi pasar, kacang telur, Kota Tomohon

\section{PENDAHULUAN}

\section{Latar Belakang}

Pemahaman yang baik mengenai pelanggan, akan mendorong manajemen untuk memahami dengan benar apa yang menjadi keinginan dan kebutuhan konsumen. Dengan mengetahui keinginan dan kebutuhan konsumen, perusahaan dituntut untuk mampu menyediakan produk atau jasa yang baik bagi konsumen. Saat perusahaan mampu menciptakan atau menyediakan produk atau jasa yang baik sesuai 
dengan keinginan dan kebutuhan konsumen dapat dipastikan konsumen akan membeli produk atau jasa perusahaan tersebut. Kemampuan perusahaan untuk memahami keinginan dan kebutuhan konsumen dan menyediakan produk atau jasa yang dinginkan dan dibutuhkan konsumen dikenal dengan istilah orientasi pada pasar atau market orientation (Narver dan Slater,1990).

Menurut Wiyono (2013) orientasi pasar merupakan kemampuan perusahaan untuk mengetahui dan merespon konsumen. Orientasi pasar didefinisikan sebagai pengumpulan secara luas intelejen pasar yang berkaitan dengan kebutuhan pelanggan sekarang atau masa mendatang, penyebarluasan intelejen diantara departemen-departemen, respon dan organisasi terhadap intelejen tersebut (Alam, 2013).

Orientasi pasar sebagai konstruk tunggal menurut Narver dan Slater (1990) seperti dikutip Alam (2013) terdiri dari tiga dimensi yaitu, orientasi pada pelanggan, orientasi pada pesaing, dan koordinasi antar fungsi. Orientasi pelanggan adalah pemahaman perusahaan terhadap target buyer sehingga dapat menciptakan superior value kepada mereka secara terus-menerus. Orientasi pada pesaing adalah sebagai pemahaman akan kekuatan dan kelemahan jangka pendek serta kapabilitas dan strategi jangka panjang dari para pesaing yang ada maupun pesaing potensial. Penerapan orientasi pesaing mempunyai dua tujuan, yaitu dalam jangka pendek dan jangka panjang. Koordinasi antar fungsi adalah merefleksikan pendayagunaan secara terkoordinasi dari seluruh sumber daya yang ada dalam perusahaan dalam rangka menciptakan superior costumer value bagi pembeli sasaran.

Dalam merspon kebutuhan perusahaan, orientasi pada pasar yang baik dari sebuah perusahaan akan memberikan kontribusi pada penerapan strategi pemasaran yang baik oleh pihak manajemen, hal ini tentunya akan berdampak pada tingkat keefektifitasan kinerja perusahaan. Kinerja perusahaan akan semakin baik seiring dengan semakin baiknya orientasi perusahaan pada pasar sasaran. Kinerja didefinisikan sebagai hasil kerja secara kualitas dan kuantitas yang dapat dicapai oleh seseorang atau organisasi (Mangkunegara,2001).

Perkembangan perusahaan yang baik akan meningkatkan daya saing perusahaan khususnya dalam persaingan bisnis. Sebagian orang beralih kevegetarian karena alasan kesehatan. Hal ini tentunya memicu pada salah satu jenis produk makanan kecil yaitu kacang-kacangan, dalam hal ini kacang telur di Kota Tomohon. Kebutuhan konsumen akan pilihan makanan memicu banyak pengusaha untuk menekuni bisnis tersebut. Persaingan dalam produk makanan ini menuntut perusahaan untuk memiliki orientasi pada pasar. Hal ini dilakukan dengan tujuan untuk meningkatkan kinerja perusahaan.

UD Bintang Lima merupakan usaha dagang yang bergerak di industri pengolahan berbahan baku Kacang Tanah. UD Bintang Lima ini terletak di Kelurahan Paslaten 2 Kecamatan Tomohon Timur Kota Tomohon. Usaha ini berdiri sejak tahun 2005. Usaha ini memiliki jumlah tenaga kerja sebanyak 12 orang. Kacang Telur ini ada yang di jual di Toko dan di Rumah Makan. Orientasi pasar dalam UD. Bintang Lima dalam hal ini Kacang Telur, dapat dikatakan sukses. Yaitu karena adanya usaha, kerja sama antara para karyawan serta pimpinan perusahaan dalam mengelola akan berkembangnya usaha mereka ini. Sehingga dapat dikatakan perusahaan ini memiliki nilai unggul (superior value).

\section{Definisi Orientasi Pasar}

Orientasi pasar merupakan sesuatu yang penting bagi perusahaan dalam kebutuhan pelanggan dimana perusahaan harus selalu dekat dengan pasarnya. Menurut Pramono dan Waridin (2006) orientasi pasar adalah kemampuan untuk mencermati kekuatan dan kelemahan pesaing dan strategi-strategi yang dilakukan oleh pesaing dalam suatu orientasi pasar.

Menurut Narver dan Slater (1994) orientasi pasar adalah organisasi yang paling efektif dan efisien untuk menciptakan perilakuperilaku yang dapat menghasilkan suatu yang terbaik bagi pemmbeli serta menghasilkan superior performance bagi perusahaan. Orientasi pasar merupakan penetapan sasaran konsumen strategis dan membangun organisasi yang berfokus pada layanan konsumen, memberikan dasar persaingan yang berfokus kedalam, memberi layanan yang sesuai dengan harapan para konsumen, sehingga berhasil memenangkan suatu persaingan (Craven, 1994).

Konsep utama dalam orientasi pasar adalah orientasi pelanggan dan orientasi pesaing. Orientasi pasar merupakan suatu filosofi dalam strategi pemasaran yang menganggap bahwa penjualan produk tidak tergantung pada strategi penjualan tetapi lebih pada keputusan konsumen dalam membeli produk. Oleh karena itu, membutuhkan perhatian secara tepat pada orientasi pelanggan dan orientasi pesaing dalam rangka menyediakan kebutuhan dan keinginan 
konsumen dengan memberi nilai terbaik (Lamb, 2001).

Komponen orientasi pasar (market orientation) menurut Narver \& Slater(1990) yaitu dalam skala MKTOR terbagi atas tiga, yaitu : Orientasi Pelanggan, Orientasi Pesaing, dan Koordinasi antar Fungsi.

\section{Orientasi Pelanggan}

Menurut Kotler (2007) apa yang menjadi keinginan pelanggan lebih penting dibandingkan dengan produk yang saat ini dijual kepada pelanggan. Pemasaran menurut Kara(2005) seperti dikutip Adinoto (2012) harus memakai konsep bagaimana perusahaan mengetahui apa yang diinginkan pelanggan atau konsumen dan memenuhinya dengan meletakkan kepuasan serta nilai-nilai pelanggan sebagai hal yang utama dan transaksi sebagai dasar analisis. Oleh karena itu, orientasi pasar merupakan implementasi dari konsep pemasaran, maka bisa disimpulkan bahwa perusahaan yang berorientasi pasar adalah perusahaan yang tindakan-tindakannya konsisten dengan konsep pemasaran.

Perusahaan yang berorientasi pada pelanggan berupaya menggali apa yang dapat disediakan perusahaan dengan membuat barang atau jasa yang terbaik. Keunikan produk yang dikembangkan oleh perusahaan akan menjadi unsur pembeda dibanding dengan produk perusahaan lain, karena itu produk yang berkualitas dan unik diharapkan menjadi alternatif pilihan konsumen dan juga mampu menciptakan kepuasan baginya. Kepuasan konsumen merupakan sasaran strategi jangka panjang, karena diharapkan loyalitas konsumen akan tercipta dengan sendirinya dan tingkat penjualanpun diharapkan meningkat dari waktu ke waktu seiring dengan terpeliharanya kepentingan pelanggan dan kemampuan mendeteksi model strategi yang dikembangkan pesaingnya. Sehingga perusahaan mampu memposisikan diri pada keunggulan strategi yang unik, dan tidak mudah ditiru oleh para pesaingnya, serta pertumbuhan tingkat penjualan dapat terjaga, dan komitmen para pelanggan menjadi semakin kuat (Wahyudiono, 2013).

\section{Orientasi Pesaing}

Orientasi pesaing berarti pemahaman yang dimiliki penjual dalam memahami kekuatankekuatan jangka pendek, kelemahan-kelemahan, kapabilitas-kapabilitas dan strategi-strategi jangka panjang baik dari pesaing utamanya saat ini maupun pesaing-pesaing utama. Menurut Day and
Wensley (2010) seperti dikutip Wulandari (2013) kemampuan manajemen mengenali pesaingnya akan membantu dan menggali berbagai informasi mengenai apa dan bagaimana pesaing menjalankan bisnis serta model strategi yang diterapkan. Sehingga manajemen memperoleh kepastian bahwa strategi dan aktivitas apapun yang dilakukan perusahaan tidak didahului oleh pesaingnya.

Perusahaan yang dapat meningkatkan efektivitas perusahaannya, profitabilitas yang akan diperoleh juga akan meningkat. Hal ini penting dalam menjamin kepastian bahwa perusahaan memiliki keunggulan yang tidak dapat disamai oleh pesaingnya. Seandainya pesing akan menirunya maka cukup mahal biaya yang harus dikorbankan, shingga perusahaan selalu dapat menempatkan posisi dirinya pada posisi terdepan dibanding para pesaingnya.

Orientasi pesaing dapat dinyatakan melalui monitoring atau informasi mengenai pesaing dan menyebarluaskan berbagai informasi tersebut, pada semua fungsi yang ada dalam perusahaan. Perusahaan yang berorientasi pada pesaing, akan menggunakan sebagian besar waktunya untuk melacak penggunaan strategi dan pangsa pasar pesaing, serta berusaha menemukan strategi untuk melawannya (Zhou, 2005).

\section{Koordinasi Antar Fungsi}

Menurut Zhou (2005) koordinasi antar fungsi dalam organisasi harus mampu melakukan peran sebagai :

1. Mendistribusikan sumber daya perusahaan kepada unit bisnis lain yang ada didalamnya.

2. Semua fungsi harus dimanfaatkan untuk memahami pelanggannya.

3. Mendistribusikan semua informasi untuk semua fungsi.

4. Semua fungsi harus diintegrasikan untuk mendukung strategi perusahaan.

5. Semua fungsi harus memberi kontribusi dalam menciptakan nilai pelanggan.

Koordinasi antar fungsi di dalam organisasi harus diarahkan untuk memahami kebutuhan pelanggan dengan memberi nilai terbaik dibanding pesaingnya, sehingga tercipta kepuasan bagi pelanggannya. Koordinasi antar fungsi mengidentifikasikan kemampuan yang dibutuhkan oleh organisai dalam rangka membentuk rantai nilai yang meliputi aktivitas utama dan aktivitas pendukung (Zhou, 2005).

Perusahaan harus memiliki kemampuan khusus dengan tugas individual untuk diintegrasikan ke dalam fungsi yang lebih luas 
cakupannya, seperti kemampuan pemasaran, riset, dan pengembangan. Integrasi antar fungsi dalam organisasi memerlukan sumber daya, khususnya pengetahuan dan keahlian dari setiap pekerja sehingga dapat mendukung organisasi dalam menyajikan nilai terbaik bagi pelanggannya.

\section{Kinerja Perusahaan}

Kinerja perusahaan merupakan faktor yang umum digunakan untuk mengukur dampak dari sebuah strategi perusahaan. Strategi perusahaan selalu diarahkan untuk menghasilkan kinerja perusahaan seperti volume penjualan, porsi pasar, dan tingkat pertumbuhan penjualan maupun kinerja keuangan. Pengukuran kinerja menggunakan aktivitas-aktivitas perusahaan yang menghasilkan kinerja yaitu unit yang terjual dan perputaran pelanggan (Ferdinand, 2000).

Pertumbuhan penjualan merupakan konsep untuk mengukur prestasi pasar suatu produk. Pertumbuhan penjualan merupakan sumber pertumbuhan pangsa pasar. Pertumbuhan penjualan digunakan untuk semua peneliti sebagai salah satu variabel pembentuk kinerja pasar. Kinerja pasar merupakan bagian dari kinerja perusahaan (Ferdinand, 2000).

\section{Penelitian Orientasi Pasar (Market Orientation)}

Riset akademik tentang orientasi pasar berfokus pada konsekuensi atau dampak orientasi pasar terhadap kinerja bisnis. Sampelnya biasanya adalah para manajer, baik CEO maupun manajer pemasaran. Mereka diminta menilai tingkat orientasi pasar perusahaannya dalam sejumlah dimensi yaitu dalam orientasi pelanggan, orientasi pesaing maupun koordinasi antar fungsi. Selain itu, ukuran-ukuran karakteristik, sumber daya, dan kompetensi organisasi, serta konteks pasar, industri dan teknologi juga diikutsertakan dalam analisis dan digunakan sebagai moderating variables, mediating variables, contextual variables untuk menguji hubungan antara orientasi pasar dan kinerja bisnis. Kinerja bisnis diukur dengan berbagai macam cara, diantaranya, perepsi manajer terhadap kinerja organisasinya, laba aktual, pertumbuhan penjualan, pangsa pasar, maupun indikator kinerja harga saham.

Menurut Cano (2004) orientasi pasar merupakan determinan kinerja bisnis yang signifikan. Selain itu, korelasi antara orientasi pasar dan kinerja bisnis lebih kuat pada konteks organisasi jasa dibandingkan perusahaan manufaktur dan lebih kuat pula pada organisasi nirlaba dibandingkan organisasi bisnis. Kirca (2005) menyimpulkan bahwa hubungan antara orientasi pasar dan kinerja bisnis lebih kuat pada perusahaan manufaktur, di negara yang budayanya bercirikan power-distance dan uncertainty-avoidance lebih rendah, dan pada studi yang menggunakan indikator kinerja subyektif.

\section{Tantangan Riset Orientasi Pasar (Market Orientation)}

Orientasi pasar (market orientation) tidak berarti terhindar dari kritik. Harris (2003), misalnya, mengkritik bahwa ancangan- ancangan pengukuran orientasi pasar yang ada cenderung non-komparatif. Ia mendasari kritiknya pada tiga argumentasi utama. Pertama, pengukuran orientasi pasar terlalu bergantung secara eksklusif pada laporan perseptual para anggota organisasi atau manajer. Ironisnya, perspektif pasar atau pelanggan cenderung terabaikan. Kedua, walaupun orientasi pasar dipahami sebagai konsep komparatif, kenyataannya ancangan- ancangan yang ada lebih berfokus pada persepsi manajemen terhadap aktivitas dan perilaku organisasinya dan bukan pada tingkat perbandingan aktivitas dan perilaku tersebut dengan para pesaing. dengan kata lain, orientasi pasar cenderung diukur tanpa mempertimbangkan faktor pesaing secara langsung. Ketiga, mayoritas aplikasi pengukuran orientasi pasar mengandalkan self-report individual tunggal dalam setiap unit bisnis atau perusahaan. Secara metodologis, hal ini sangat lemah dan berpotensi menghasilkan bias dan menyesatkan (misleading).

Sebagai alternatif solusinya, Harris (2003) mengajukan ancangan multi perspektif dan multi informan untuk mengukur orientasi pasar, yang difokuskan pada pengukuran persepsi para pelanggan, pesaing dan anggota internal organisasi terhadap orientasi pasar sebuah organisasi. Juga lebih memprioritaskan kelengkapan (completeness). Orientasi pasar keseluruhan (overall market orientation) bisa dihitung dengan cara menjumlahkan ketiga dimensi, dimana koordinasi antar fungsi diukur oleh eksekutif perusahaan, orientasi pelanggan dinilai oleh pelanggan, dan orientasi pesaing dinilai oleh pesaing.

\section{Pengukuran Orientasi Pasar}

Pengukuran orientasi pasar mencakup tiga komponen yaitu orientasi pelanggan, orientasi pesaing dan koordinasi antar fungsi. Tabel 1 menjelaskan unsur khusus menurut ketiga komponen tersebut. 
Tabel 1. Pengukuran Orientasi Pasar menurut unsur khusus berdasarkan tiga komponen utama

\begin{tabular}{lcll}
\hline No & \multicolumn{1}{c}{ Komponen } & & \multicolumn{1}{c}{ Item spesifik } \\
\hline 1. & Orientasi Pelanggan & - & Komitmen pelanggan \\
& & - & Penciptaan nilain pelanggan \\
& & - Pemahaman kebutuhan pelanggan \\
& & - & Tujuan kepuasan pelanggan \\
& & - & Lengukuran kepuasan pelanggan \\
& Orientasi Pesaing & - & Wiraniaga berbagi informasi pesaing \\
& & - & Bereaksi cepat terhadap tindakan pesaing \\
& & - & Manajer puncak mendiskusikan strategi pesaing \\
& & - & Menargetkan peluang bagi keunggulan kompetitif \\
\hline 3. & Koordinasi antar fungsi & - & Informasi dibagi antar fungsi \\
& & - & Integrasi fungsional dalam strategi \\
& & - & Semua fungsi berkontribusi terhadap nilai pelanggan \\
& & - & Berbagi sumber daya dengan unit bisnis lain \\
\hline
\end{tabular}

Sumber: Diadaptasi dari Narver \& Slater (1990)

\section{Rumusan Masalah}

Berdasarkan latar belakang yang telah dikemukakan, dapat dirumuskan bahwa masalah dalam penelitian ini adalah bagaimana orientasi pasar (orientasi pada pelanggan, orientasi pada pesaing, koordinasi antar fungsi) pada UD Bintang Lima?

\section{Tujuan dan Manfaat Penelitian}

Tujuan penelitian ini yaitu untuk mengetahui orientasi pasar (orientasi pada pelanggan, orientasi pada pesaing, koordinasi antar fungsi). Manfaatnya yaitu untuk memberikan pengetahuan, memberikan informasi serta bermanfaat bagi para pengusaha dalam mengelola, meningkatkan dan menjalankan usahanya.

\section{METODOLOGI PENELITIAN}

\section{Waktu dan Tempat Penelitian}

Penelitian ini dilaksanakan pada UD. Bintang Lima yang bertempat di Kelurahan Paslaten 2 Kecamatan Tomohon Timur Kota Tomohon. Penelitian ini berlangsung selama 3 bulan (dari bulan Februari sampai dengan April 2016).

\section{Metode Pengumpulan Data}

Data yang digunakan dalam penelitian ini adalah data primer dengan pemgambilan data menggunakan metode survey serta menggunakan kuesioner, yaitu dengan menyebarkan kuesioner pada karyawan-karyawan dan pimpinan perusahaan. Kuesioner digunakan untuk mengetahui orientasi pada pelanggan, orientasi pada pesaing, dan koordinasi antar fungsi.

\section{Konsep Pengukuran Variabel}

1. Orientasi Pelanggan,

a. Komitmen para pelanggan diukur dari kepercayaan pelanggan dan membangun hubungan erat dengan pelanggan.

b. Penciptaan nilai pelanggan, diukur dari kualitas dan kepuasan pelanggan.

c. Tujuan kepuasan pelanggan diukur dari kacangnya gurih dan rasanya enak.

d. Layanan purnajual diukur dari adanya pelayanan pemeliharaan dan kebutuhan pelanggan

2. Orientasi Pesaing,

a. Wiraniaga berbagi informasi pesaing diukur dari perusahaan lain yang ingin menjadi agen.

b. Bereaksi cepat terhadap tindakan pesaing diukur dari merespon tindakan pesaing dan bereaksi terhadap strategi pesaing.

3. Koordinasi antar Fungsi,

a. Kontak pelanggan antar fungsi diukur dari interaksi staf pemasaran.

b. Semua fungsi berkontribusi terhadap nilai pelanggan diukur dari peran dalam keikutsertaan dalam perusahaan.

c. Adanya budaya saling bekerja sama diukur dari sifat dan sikap 


\section{Metode Analisis Data}

Analisis data yang digunakan dalam penelitian ini adalah secara deskriptif. Dianalisis dengan menggunakan skala Likert. Data yang dihasilkan dengan menggunakan skala Likert dalam analisis ini akan diketahui orientasi pelanggan, orientasi pesaing dan koordinasi antar fungsi pada UD Bintang Lima. Dalam penelitian ini di susun 15 pertanyaaan dengan total responden 13 orang. Jawaban setiap instrumen yang menggunakan skala Likert, yang berupa kata kata, antara lain :

$\begin{array}{ll}\mathrm{SB} & =\text { Sangat Baik } \\ \mathrm{B} & =\text { Baik } \\ \mathrm{CB} & =\text { Cukup Baik } \\ \mathrm{TB} & =\text { Tidak Baik }\end{array}$

$0 \quad 13 \quad 26$

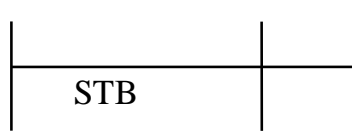

diberi skor 5

diberi skor 4

diberi skor 3

diberi skor 2

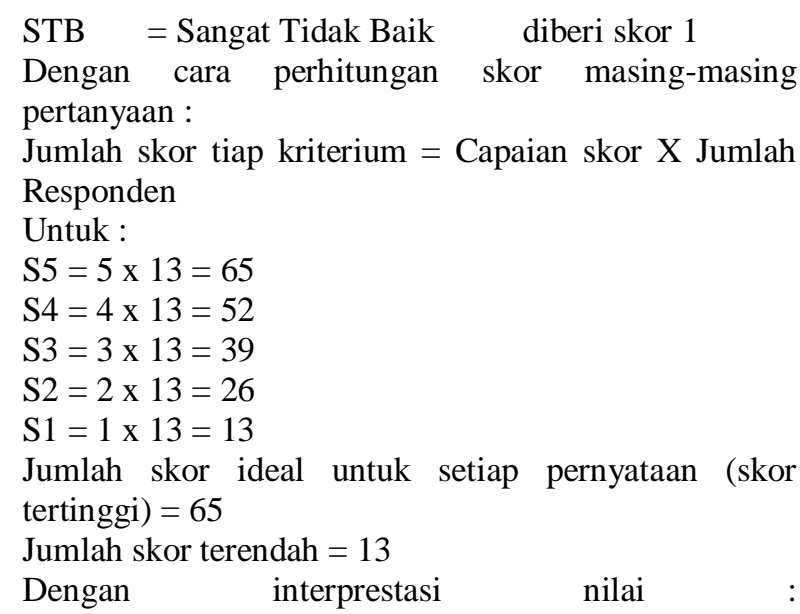

Cara perhitungan skor keseluruhan untuk mengetahui orientasi pasar

Jumlah skor seluruh kriterium $=$ Capaian Jumlah Skor $X$ Jumlah Responden X Instrumen Pertanyaan

Untuk :

$\mathrm{S} 5=5 \times 13 \times 15=975$

$\mathrm{S} 4=4 \times 13 \times 15=780$

$\mathrm{S} 3=3 \times 13 \times 15=585$

$\mathrm{S} 2=2 \times 13 \times 15=390$

$\mathrm{S} 1=1 \times 13 \times 15=195$

Jumlah skor

ideal keseluruhan untuk keseluruhan

pernyataan $=975$

(tertinggi)

Jumlah skor rendah $=195$

$\begin{array}{llllll}0 & 195 & 390 & 585 & 780 & 975\end{array}$

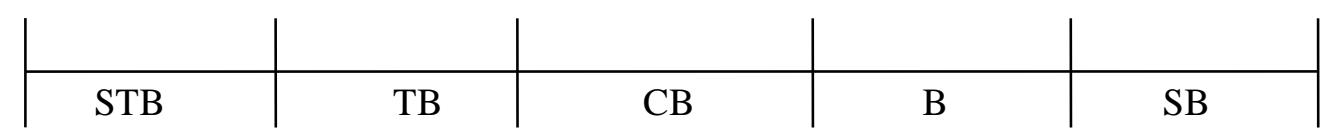

Tingkat Orientasi Pasar $=\frac{\text { Jumlah Skor Hasil Pengumpulan Data }}{\text { Jumlah skor ideal (tertinggi) }} \times 100 \%$

Dengan Interpretasi nilai:

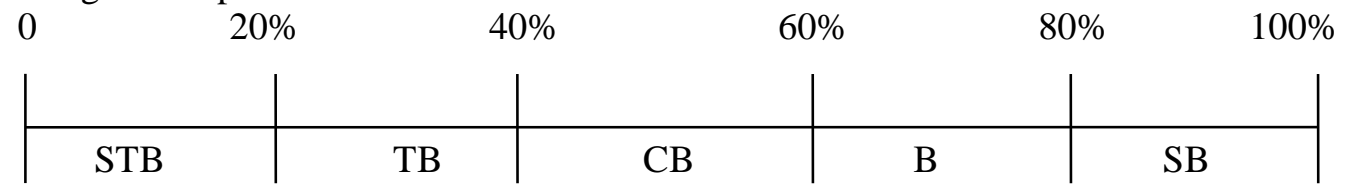

Keterangan kriteria interpretasi skor Orientasi Pasar (Riduwan, 2012):

Angka $0 \%-20 \%=$ Sangat Tidak Baik

Angka 20\%-40\%= Tidak Baik

Angka 40\%-60\%= Cukup Baik

Angka 60\%-80\%= Baik

Angka $80 \%-100 \%=$ Sangat Baik 


\section{HASIL DAN PEMBAHASAN}

\section{Profil dan Deskripsi UD Bintang Lima}

Kacang tanah dari segi kandungan nutrisinya banyak mengandung lemak dan protein. Oleh karena itu, dapat digunakan sebagai bahan utama dalam pembuatan makanan ringan, yaitu salah satunya adalah kacang telur. Kacang telur adalah makanan ringan yang dibuat dengan bahan dasar kacang tanah dan berbentuk bulat kecil serta berwarna putih.

Kacang tanah dapat diolah menjadi berbagai produk seperti kacang telur, dan kacang atom. Kacang telur merupakan kacang tanah yang dibalut dengan terigu, direkatkan dengan adonan bumbu dan kanji. Bahan yang digunakan untuk pembuatan kacang telur menggunakan telur, gula pasir dan margarine.

UD Bintang Lima mengelola produk kacang telur atau disebut juga kacang Hai. Pengelolah produk ini dipimpin oleh seorang Bapak yaitu Bapak Sutrisno, ada juga istrinya yang mengelolah produk kacang Zico. Pengelolaan kacang Zico tidak bersamaan dengan tempat pengelolaan kacang telur atau kacang Hai. Tempat pengelolaan kacang Zico terletak di belakang UD Bintang Lima. Perbedaan dari kedua kacang ini yaitu Kacang Telur atau Kacang Hai bentuk bulatannya lebih besar, sedangkan Kacang Zico bentuknya sedikit kecil.

UD Bintang Lima adalah perusahaan perseorangan atau usaha dagang (UD) dan merupakan bentuk usaha yang paling sederhana karena pengusahanya hanya satu orang. Usaha ini didirikan pada tahun 2005 oleh Bapak Sutrisno. UD Bintang Lima mengelola produk kacang telur yang berbahan baku kacang tanah. UD Bintang Lima terletak di Kelurahan Paslaten 2 Kecamatan Tomohon Timur Kota Tomohon.

UD Bintang Lima memiliki struktur organisasi yaitu Pemilik 1 orang (Pemimpin), membersihkan kacang 2 orang, pengelolaan/ produksi 1 orang, penggorengan 1 orang, pengemasan 3 orang, pemasaran 5 orang. Jadi, keseluruhan responden yaitu 13 orang. Daerah pemasaran produk ini yaitu didaerah pertokoan Tomohon, Rumah Makan, Manado, Ratatotok, dan Gorontalo.

\section{Orientasi Pasar}

Orientasi pasar merupakan budaya bisnis yang mampu secara efektif dan efisien dengan menciptakan perilaku karyawan dan perubahan dalam kebutuhan pelanggan dimana perusahaan menyadari bahwa mereka harus dekat dengan pasarnya. Komponen orientasi pasar (market orientation) terdapat dua bagian yaitu skala MARKOR menurut Kohli \& Jaworski (1990) dan skala MKTOR menurut Narver \& Slater(1990). Pada skala MARKOR terdapat tiga komponen yaitu pengumpulan intelijensi pasar, penyebarluasan intelijensi pasar, dan responsivitas atas intelijensi pasar. Sedangkan pada skala MKTOR terdapat tiga komponen yaitu orientasi pelanggan, orientasi pesaing, dan koordinasi antar fungsi.

\section{Orientasi Pelanggan}

Orientasi pelanggan diartikan sebagai pemahaman yang memadai tentang target beli pelanggan dengan tujuan agar dapat menciptakan nilai unggul bagi pembeli secara terus-menerus. Pemahaman disini mencakup pemahaman terhadap seluruh rantai nilai pembeli, baik pada saat terkini maupun pada saat perkembangannya dimasa yang akan datang. Dengan adanya informasi tersebut maka perusahaan penjual akan memahami siapa saja pelanggan potensialnya, baik pada saat ini maupun pada masa yang akan datang dan apa yang mereka inginkan untuk saat ini dan saat mendatang.

\section{Memahami Kebutuhan Pelanggan}

Unsur yang paling penting dalam bisnis adalah konsep hubungan pelanggan. Tujuan dari hubungan pelanggan adalah membuat pelanggan merasa dihargai, mengidentifikasi kemungkinan masalah dan untuk mengetahui kebutuhan yang mungkin berguna dalam melayani pengembangan produk.

UD Bintang Lima telah memahami kebutuhan pelanggan yaitu membuat pelanggan dihargai dan mempunyai hubungan yang baik dengan pelanggan.

Tabel 2 menjelaskan tentang pemahaman kebutuhan pelanggan yang dimiliki karyawan UD Bintang Lima. 
Tabel 2. UD Bintang Lima memahami kebutuhan pelanggan secara lebih baik dibandingkan para pesaing

\begin{tabular}{lcccc}
\hline $\begin{array}{c}\text { Alternatif } \\
\text { Jawaban }\end{array}$ & $\begin{array}{c}\text { Alternatif } \\
\text { Skor }\end{array}$ & $\begin{array}{c}\text { Jumlah } \\
\text { Responden } \\
\text { (Orang) }\end{array}$ & $\begin{array}{c}\text { Presentase } \\
\text { Responden }\end{array}$ & $\begin{array}{c}\text { Total } \\
\text { Skor }\end{array}$ \\
\hline $\begin{array}{l}\text { Sangat } \\
\text { Baik }\end{array}$ & 5 & - & - & - \\
Baik & 4 & 13 & 100 & 52 \\
Cukup & 3 & - & - & - \\
Baik & 2 & - & - & - \\
Tidak & 1 & - & - & - \\
Baik & & & & \\
Sangat & & & $\mathbf{1 0 0}$ & $\mathbf{5 2}$ \\
Tidak & & & & \\
Baik & & $\mathbf{1 3}$ & $\mathbf{1 0 0}$ & \\
\hline Total & &
\end{tabular}

Sumber :Diolah dari data primer 2016

Hasil penelitian ini menunjukkan bahwa 100 persen responden (13 orang) memilih Baik dengan pernyataan UD Bintang lima memahami kebutuhan pelanggan dibandingkan para pesaing. Angka Indeks Orientasi Pasar mengenai kebutuhan pelanggan (pernyataan nomor 1) yaitu 80 persen sehingga interpretasi nilainya tergolong Baik karena UD Bintang lima memahami akan kebutuhan pelanggan dengan memberikan pelayanan yang baik kepada para pelanggan. Seperti selalu terbuka dengan keluhan pelanggan, komentar pelanggan harus didengarkan, diperhatikan, dan ditindaklanjuti.

Menciptakan nilai bagi pelanggan

Nilai yang dikirkan pelanggan merupakan kerangka kerja yang bermanfaat yang berlaku dalam banyak situasi dan menghasilkan wawasan yang luas. Pemasar dapat menngkatkan nilai penawaran pelanggan melalui beberapa kombinasi peningkatan manfaat ekonomi dan mengurangi satu jenis biaya atau lebih agar dapat memuaskan pelanggan.

UD ini menciptakan nilai bagi pelanggan yaitu kepuasan dari produk yang akan dibeli oleh para pelanggan, melalui penciptaan nilai yang akan memuaskan pelanggan secara lebih baik.

Tabel 3 menjelaskan tentang penciptaan nilai bagi pelanggan dari UD Bintang Lima.
Tabel 3. UD Bintang Lima menciptakan nilai bagi pelanggan secara lebih baik dibandingkan para pesaing

\begin{tabular}{lcccc}
\hline $\begin{array}{c}\text { Alternatif } \\
\text { Jawaban }\end{array}$ & $\begin{array}{c}\text { Alternatif } \\
\text { Skor }\end{array}$ & $\begin{array}{c}\text { Jumlah } \\
\text { Responden } \\
\text { (Orang) }\end{array}$ & $\begin{array}{c}\text { Presentase } \\
\text { Responden }\end{array}$ & $\begin{array}{c}\text { Total } \\
\text { Skor }\end{array}$ \\
\hline Sangat Baik & 5 & - & - & - \\
Baik & 4 & 11 & 84,6 & 44 \\
Cukup Baik & 3 & 2 & 15,4 & 6 \\
Tidak Baik & 2 & - & - & - \\
Sangat & 1 & - & - & - \\
Tidak Baik & & & & \\
\hline Total & & $\mathbf{1 3}$ & $\mathbf{1 0 0}$ & $\mathbf{5 0}$ \\
\hline
\end{tabular}

Sumber : Diolah dari data primer 2016

Hasil penelitian ini menunjukkan bahwa 84,6 persen responden (11 orang) memilih Baik dalam menciptakan nilai bagi pelanggan, yaitu UD ini dapat menciptakan nilai produk yang memuaskan pelanggan. Sedangkan 15,4 persen responden ( 2 orang) memilih Cukup Baik karena menurut mereka UD ini dalam menciptakan nilai produk yang memuaskan pelanggan masih Cukup Baik. Angka Indeks Orientasi Pasar mengenai pernyataan nomor 2 yaitu 76,92 persen sehingga interpretasi nilainya Baik walaupun ada yang memilih cukup baik tapi UD Bintang lima menyadari harus menciptakan nilai bagi pelanggan secara lebih baik. Seperti memahami keinginan pelanggan disaat mereka membeli akan produk tersebut.

Kurang berfokus pada komitmen pelanggan.

Fokus terhadap pelanggan bukan berarti telah memenuhi tuntutan dan persyaratan, tetapi memerlukan strategi yang berjalan untuk memenuhi keperluan pelanggan. Tabel 4 menjelaskan tentang kurang berfokus pada komitmen pelanggan dilihat pada UD Bintang Lima.

Tabel 4. UD Bintang Lima kurang berfokus pada komitmen pelanggan dibandingkan para pesaing

\begin{tabular}{|c|c|c|c|c|}
\hline $\begin{array}{c}\text { Alternatif } \\
\text { Jawaban }\end{array}$ & $\begin{array}{l}\text { Alternatif } \\
\text { Skor }\end{array}$ & $\begin{array}{c}\text { Jumlah } \\
\text { Responden } \\
\text { (Orang) }\end{array}$ & $\begin{array}{l}\text { Presentase } \\
\text { Responden }\end{array}$ & $\begin{array}{l}\text { Total } \\
\text { Skor }\end{array}$ \\
\hline $\begin{array}{l}\text { Sangat } \\
\text { Baik }\end{array}$ & 5 & - & - & - \\
\hline Baik & 4 & - & - & - \\
\hline $\begin{array}{l}\text { Cukup } \\
\text { Baik }\end{array}$ & 3 & 4 & 30,8 & 12 \\
\hline $\begin{array}{l}\text { Tidak } \\
\text { Baik }\end{array}$ & 2 & 9 & 69,2 & 18 \\
\hline $\begin{array}{l}\text { Sangat } \\
\text { Tidak } \\
\text { Baik } \\
\end{array}$ & 1 & - & - & - \\
\hline Total & & 13 & 100 & 30 \\
\hline
\end{tabular}


Hasil penelitian ini menunjukkan bahwa 30,8 persen responden (4 orang) memilih cukup baik, sedangkan 69,2 persen responden ( 9 orang) memilih tidak baik dengan pernyataan tersebut karena mereka percaya bahwa UD ini berfokus pada komitmen pelanggan yaitu dengan memiliki strategi sendiri untuk memenuhi keperluan pelanggan. Seperti pemberian bonus pada produk tersebut, contohnya sendok. Dan perubahan kemasan pada produk tersebut.

\section{Kurang memperhatikan kepuasan pelanggan}

Kepuasan pelanggan dijamin dengan menghasilkan produk berkualitas, kepuasan berimplikasi pada perbaikan terus-menerus sehingga kualitas harus diperbahurui setiap saat agar pelanggan tetap puas.

UD ini tidak hanya melihat dari komitmen pelanggan, tetapi ada juga kepuasan pelanggan. UD ini memperhatikan kepuasan pelanggan dilihat dari produk yang berkualitas.

Tabel 5 menjelaskan tentang kurang memperhatikan kepuasan pelanggan dilihat dari usaha dagang pada Bintang Lima.

\begin{tabular}{lcccc}
$\begin{array}{l}\text { Tabel } \\
\text { memperhatikan } \\
\text { dibandingkan para }\end{array}$ & $\begin{array}{c}\text { Bintang } \\
\text { kepuasan }\end{array}$ & $\begin{array}{c}\text { Lima } \\
\text { pesaing }\end{array}$ & $\begin{array}{r}\text { kurang } \\
\text { pelanggan }\end{array}$ \\
\hline $\begin{array}{l}\text { Alternatif } \\
\text { Jawaban }\end{array}$ & $\begin{array}{c}\text { Alternatif } \\
\text { Skor }\end{array}$ & $\begin{array}{c}\text { Jumlah } \\
\text { Responden } \\
\text { (Orang) }\end{array}$ & $\begin{array}{c}\text { Presentase } \\
\text { Responden }\end{array}$ & $\begin{array}{c}\text { Total } \\
\text { Skor }\end{array}$ \\
\hline $\begin{array}{l}\text { Sangat } \\
\text { Baik }\end{array}$ & 5 & 7 & 53,8 & 35 \\
Baik & 4 & 6 & 46,2 & 24 \\
$\begin{array}{l}\text { Cukup } \\
\text { Baik } \\
\text { Tidak }\end{array}$ & 3 & - & - & - \\
$\begin{array}{l}\text { Baik } \\
\text { Sangat }\end{array}$ & 2 & - & - & - \\
Tidak & 1 & - & - & - \\
Baik & & & & \\
\hline Total & & $\mathbf{1 3}$ & $\mathbf{1 0 0}$ & $\mathbf{5 9}$ \\
\hline Sumber & & & & \\
\hline
\end{tabular}

Sumber : Diolah dari data primer 2016

Hasil penelitian ini menunjukkan bahwa 53,8 persen responden (7 orang) memilih sangat baik, sedangkan 46,2 persen responden (6 orang) memilih baik dalam kurangnya memperhatikan kepuasan pelanggan, karena UD ini memperhatikan kepuasan pelanggan. Seperti memperhatikan dan memberikan kesempatan yang luas kepada pelanggan untuk menyampaikan saran dan keluhan pada produk.
Merespon tuntutan kebutuhan pelanggan

Kebutuhan pelanggan merupakan suatu sikap untuk memenuhi kebutuhan pelanggan, juga secara lebih efektif melakukan layanan purnajual yaitu pelayanan pemeliharaan dari produk yang akan dibeli.

UD Bintang Lima melihat bagaimana merespon tuntutan kebutuhan pelanggan secara lebih efektif yaitu dengan melakukan layanan purnajual, sehingga para pelanggan mendapat pelayanan yang baik dan dapat terpenuhi akan kebutuhannya.

Tabel 6 menjelaskan tentang merespon tuntutan kebutuhan pelanggan secara lebih efektif.

Hasil penelitian ini menunjukkan bahwa 7,7 persen responden ( 1 orang) memilih sangat baik, sedangkan 92,3 persen responden (12 orang) memilih baik dalam merespon tuntutan kebutuhan pelanggan secara efektif, karena UD ini melakukan pelayanan yang baik terhadap tuntutan kebutuhan para pelanggannya. Yaitu, UD ini merespon akan kekurangan dari produk dengan memiliki sikap yang baik sehingga pelanggan dapat merasa puas akan produk yang dibeli. Seperti pelayanan pada produk yang telah kadaluarsa.

\section{Rekapitulasi Orientasi Pasar pada Orientasi Pelanggan}

Rekapitulasi adalah ringkasan isi atau ikhtisar pada akhir laporan atau akhir hitungan. Dari hasil perhitungan seluruh variabel pada orientasi pelanggan maka rekapitulasinya sebagai berikut.

Tabel 6. UD Bintang Lima merespon tuntutan kebutuhan pelanggan secara lebih efektif dibandingkan para pesaing

\begin{tabular}{lcccc}
\multicolumn{5}{c}{ para pesaing } \\
\hline $\begin{array}{l}\text { Alternatif } \\
\text { Jawaban }\end{array}$ & $\begin{array}{c}\text { Alternatif } \\
\text { Skor }\end{array}$ & $\begin{array}{c}\text { Jumlah } \\
\text { Responden } \\
\text { (Orang) }\end{array}$ & $\begin{array}{c}\text { Presentase } \\
\text { Responden }\end{array}$ & $\begin{array}{c}\text { Total } \\
\text { Skor }\end{array}$ \\
\hline $\begin{array}{l}\text { Sangat } \\
\text { Baik }\end{array}$ & 5 & 1 & 7,7 & 5 \\
Baik & 4 & 12 & 92,3 & 48 \\
Cukup & 3 & - & - & - \\
Baik & & - & - & - \\
Tidak & 2 & - & - & - \\
Baik & & & & \\
Sangat & 1 & $\mathbf{1 3}$ & \\
Tidak & & & $\mathbf{1 0 0}$ \\
Baik & & &
\end{tabular}


Tabel 7 menunjukkan terdapat 5 pernyataan dalam orientasi pasar pada orientasi pelanggan dimana pernyataan 4 memiliki indeks orientasi pasar tertinggi yaitu sebesar 90,76 persen, pernyataan 5 memiliki indeks orientasi pasar sebesar 81,53 persen. Pernyataan 4 dan 5 ini memiliki interpretasi sangat baik. Pernyataan 1 dan 2 memiliki interpretasi baik, dimana pernyataan 1 memiliki indeks orientasi pasar sebesar 80 persen, pernyataan 2 memiliki indeks orientasi pasar sebesar 76,92 persen. Sedangkan indeks orientasi pasar pada pernyataan 3 yaitu sebesar 46,15 persen, sehingga interpretasi cukup baik.

\section{Orientasi Pesaing}

Orientasi pesaing berarti bahwa perusahaan yang berorientasi pesaing sering dilihat sebagai perusahaan yang mempunyai strategi bagaimana membagikan informasi mengenai pesaing.

\section{Merespon tindakan pesaing}

Sebagian perusahaan kecil akan merespon persaingan dengan memberi perhatian yang tinggi pada berbagai kegiatan dan perilaku yang marketoriented. Sementara itu, dipihak lain perusahaan lain melakukan respon melalui pengendalian biaya dan potongan harga. Perusahaan akan bertindak secara rasional dengan mengembangkan strategi kompetisi dala menghadapi pesaingnya.

Tabel 7. Rekapitulasi pengukuran variabel Orientasi Pelanggan pada UD Bintang Lima

\begin{tabular}{llccc}
\hline No & \multicolumn{1}{c}{ PERNYATAAN } & $\begin{array}{c}\text { TOTAL } \\
\text { SKOR }\end{array}$ & $\begin{array}{c}\text { INDEKS } \\
\text { ORIENTASI } \\
\text { PASAR }\end{array}$ & INTERPRETASI \\
\hline $\mathbf{1}$ & $\begin{array}{l}\text { UD Bintang Lima memahami kebutuhan } \\
\text { pelanggan secara lebih baik dibandingkan para } \\
\text { pesaing }\end{array}$ & 52 & 80 & Baik \\
$\mathbf{2}$ & $\begin{array}{l}\text { UD Bintang Lima menciptakan nilai bagi } \\
\text { pelanggan secara lebih baik dibandingkan para } \\
\text { pesaing }\end{array}$ & 50 & 76,92 & Baik \\
$\mathbf{3}$ & $\begin{array}{l}\text { UD Bintang Lima kurang berfokus pada } \\
\text { komitmen pelanggan dibandingkan para pesaing }\end{array}$ & 30 & 46,15 & Cukup Baik \\
$\mathbf{4}$ & $\begin{array}{l}\text { UD Bintang Lima kurang memperhatikan } \\
\text { kepuasan pelanggan dibandingkan para pesaing }\end{array}$ & 59 & 90,76 & Sangat Baik \\
$\mathbf{5}$ & $\begin{array}{l}\text { UD Bintang Lima merespon tuntutan kebutuhan } \\
\text { pelanggan secara lebih efektif dibandingkan } \\
\text { para pesaing }\end{array}$ & 53 & 81,53 & Sangat Baik \\
\hline
\end{tabular}

Sumber : Diolah dari data primer 2016

Tabel 8 menjelaskan tentang merespon tindakan pesaing.

Tabel 8. UD Bintang Lima merespon tindakan pesaing secara lebih cepat dibandingkan para pesaing

\begin{tabular}{|c|c|c|c|c|}
\hline Alternatif Jawaban & Alternatif Skor & $\begin{array}{l}\text { Jumlah Responden } \\
\text { (Orang) }\end{array}$ & Presentase Responden & Total Skor \\
\hline Sangat Baik & 5 & - & - & - \\
\hline Baik & 4 & 2 & 15,38 & 8 \\
\hline Cukup Baik & 3 & 11 & 84,62 & 33 \\
\hline Tidak Baik & 2 & - & - & - \\
\hline Sangat Tidak Baik & 1 & - & - & - \\
\hline Total & & 13 & 100 & 41 \\
\hline
\end{tabular}

Sumber : Diolah dari data primer 2016 
Hasil penelitian ini menunjukkan bahwa 15,38 persen responden ( 2 orang) memilih baik sedangkan 84,62 persen responden (11 orang) memilih cukup baik, karena menurut sebagian pekerja pesaing masih lebih cepat dalam merespon akan tindakan pesaingnya yang dilihat dari perhatian dalam berbagai kegiatan dan perilaku dalam berorientasi pasar. Seperti pada UD ini masih kurangnya perhatian pemimpin dalam mengelola produk kacang telur.

\section{Peluang keunggulan bersaing}

Keunggulan bersaing adalah suatu manfaat yang ketika suatu perusahaan mempunyai dan menghasilkan suatu produk atau jasa yang dilihat dari pasar targetnya lebih baik. Seorang pengusaha yang mampu menghasilkan produk atau jasa rendah biaya sehingga strategi dalam menetapkan harga tidak terlalu tinggi dibandingkan dengan produk atau jasa pesaing.

Dalam usaha dagang ini menangkap peluang keunggulan bersaing secara lebih baik sehingga usaha dagang ini dapat memberikan nilai yang unggul.

Tabel 9 Menjelaskan peluang keunggulan bersaing dilihat dalam usaha dagang ini.

Tabel 9. UD Bintang Lima menangkap peluang keunggulan bersaing secara lebih baik dibadingkan para pesaing

\begin{tabular}{lcccc}
\hline $\begin{array}{l}\text { Alternatif } \\
\text { Jawaban }\end{array}$ & $\begin{array}{c}\text { Alternatif } \\
\text { Skor }\end{array}$ & $\begin{array}{c}\text { Jumlah } \\
\text { Responden } \\
\text { (Orang) }\end{array}$ & $\begin{array}{c}\text { Presentase } \\
\text { Responden }\end{array}$ & $\begin{array}{c}\text { Total } \\
\text { Skor }\end{array}$ \\
\hline Sangat & 5 & - & - & - \\
Baik & 4 & 10 & 76,92 & 40 \\
Baik & 3 & 3 & 23,08 & 9 \\
Cukup & 2 & - & - & - \\
Baik & 1 & - & - & - \\
Tidak & 2 & & & \\
Baik & & & & \\
Sangat & 1 & $\mathbf{1 3}$ & $\mathbf{1 0 0}$ & $\mathbf{4 9}$ \\
Tidak & & & & \\
Baik & & \multicolumn{5}{c}{ Total } & & & & \\
\hline Sumber: Diolah dari data primer 2016
\end{tabular}

Sumber : Diolah dari data primer 2016

Hasil penelitian ini menunjukkan bahwa 76,92 persen responden(10 orang) memilih baik karena produk atau jasa yang memiliki keunggulan dari segi harga dan nilai. Sedangkan 23,08 persen responden (3 orang) memilih cukup baik, karena masih kurangnya keunggulan bersaing dari segi harga dan nilai. Seperti pelanggan yang sensitif terhadap harga, biasanya selisih harga seribu rupiah, dengan produk atau jasa pesaing akan menjadi pertimbangan dalam membeli produk yang lebih rendah harganya.

\section{Bereaksi terhadap strategi pesaing}

Dalam menetapkan strategi pemasaran dalam bersaing, perusahaan harus memperoleh semua informasi tentang para pesaingnya. Suatu perusahaan memerlukan informasi yang lebih rinci mengenai masing-masing pesaing. Ia harus mengetahui kualitas, keistimewaan produk, layanan pelanggan, kebijakan penetapan harga, strategi tenaga penjualan.

Tabel 10 berikut menjelaskan tentang reaksi terhadap strategi/ taktik pesaing dalam menjalankan usahanya

Hasil penelitian menunjukkan bahwa 23,08 persen responden (3 orang) memilih cukup baik, sedangkan 76,92 persen responden (10 orang) memilih tidak baik karena UD ini tidak memperhatikan taktik pesaing yaitu informasi tentang para pesaingnya. UD ini hanya bereaksi sendiri akan produk yang dikelola, sperti kualitas produk yang tidak melebihi perusahaan yang lain dan penetapan harga yang tidak terlalu tinggi.

Tabel 10. UD Bintang Lima bereaksi terhadap strategi/taktik pesaing secara lebih cepat dibandingkan para pesaing

\begin{tabular}{|c|c|c|c|c|}
\hline $\begin{array}{c}\text { Alternatif } \\
\text { Jawaban }\end{array}$ & $\begin{array}{c}\text { Alternatif } \\
\text { Skor }\end{array}$ & $\begin{array}{c}\text { Jumlah } \\
\text { Responden } \\
\text { (Orang) }\end{array}$ & $\begin{array}{l}\text { Presentase } \\
\text { Responden }\end{array}$ & $\begin{array}{l}\text { Total } \\
\text { Skor }\end{array}$ \\
\hline $\begin{array}{l}\text { Sangat } \\
\text { Baik }\end{array}$ & 5 & - & - & - \\
\hline Baik & 4 & - & - & - \\
\hline $\begin{array}{l}\text { Cukup } \\
\text { Baik }\end{array}$ & 3 & 3 & 23,08 & 9 \\
\hline $\begin{array}{l}\text { Tidak } \\
\text { Baik }\end{array}$ & 2 & 10 & 76,92 & 20 \\
\hline $\begin{array}{l}\text { Sangat } \\
\text { Tidak } \\
\text { Baik }\end{array}$ & 1 & - & - & - \\
\hline Total & & 13 & 100 & 29 \\
\hline
\end{tabular}

Sumber : Diolah dari data primer 2016

Memprediksi trend industri atau sektor bisnis juga berbagi informasi pesaing yang ingin menjadi agen

Memprediksi trend industri atau sektor bisnis yaitu dilihat dari kegiatan memproses atau mengelola barang dengan menggunakan sarana an peralatan. Untuk berbagi informasi kepada 
pesaing yang ingin menjadi agen, perusahaan mampu menjalankan suatu bisnis dengan membagikan informasi kepada perusahaan yang ingin bekerja sama dengan perusahaan tersebut.

Tabel 11 berikut menjelaskan tentang prediksi trend industri atau sektor bisnis serta berbagi informasi pesaing dilihat dari perusahaan lain yang ingin bergabung

Tabel 11. UD Bintang Lima mampu memprediksi trend industri atau sektor bisnis secara lebih baik juga berbagi informasi kepada pesaing yang ingin menjadi agen

\begin{tabular}{lcccc}
\hline $\begin{array}{c}\text { Alternatif } \\
\text { Jawaban }\end{array}$ & $\begin{array}{c}\text { Alternatif } \\
\text { Skor }\end{array}$ & $\begin{array}{c}\text { Jumlah } \\
\text { Responden } \\
\text { (Orang) }\end{array}$ & $\begin{array}{c}\text { Presentase } \\
\text { Responden }\end{array}$ & $\begin{array}{c}\text { Total } \\
\text { Skor }\end{array}$ \\
\hline Sangat & 5 & - & - & - \\
Baik & 4 & - & - & - \\
Baik & 3 & - & - & - \\
Cukup & 2 & 13 & 100 & 26 \\
Baik & 1 & - & - & - \\
Tidak & & & & \\
Baik & & & $\mathbf{1 0 0}$ & $\mathbf{2 6}$ \\
Sangat & Tidak & & & \\
Baik & & $\mathbf{1 3}$ & & \\
\hline Total & &
\end{tabular}

Sumber : Diolah dari data primer 2016

Hasil penelitian ini menunjukkan bahwa 100 persen responden (13 orang) memilih tidak baik karena UD ini tidak mampu memprediksi trend industri atau sektor bisnis secara lebih baik dan tidak juga berbagi informasi kepada pesaing yang ingin menjadi agen, melainkan UD ini hanya berdiri sendiri dan menjalankan bisnis sendiri. UD ini memakai peralatan seperti dalam pembungkusan kacang.

$\underline{\text { Kompetisi dalam industri atau sektor bisnis }}$

Kompetisi mempunyai arti adanya persangan antara perusahaan untuk mencapai pangsa pasar yang lebih besar. Kompetisi antara perusahaan dalam merebutkan pelanggan akan menuju pada inovasi dan perbaikan produk dan pada harga yang lebih rendah. Kompetisi baik bagi perusahaan karena akan terus mendorong adanya inovasi, ketekunan dan membangun semangat tim. Walaupun demikian, tidak selamanya kompetisi selalu baik karena kita harus memastikan bahwa para pesaing perusahaan tidak akan mengambil pelanggan kita.
Tabel 11 menjelaskan bagaimana memahami kompetisi dalam industri atau sektor bisnis.

Tabel 12. UD Bintang Lima memahami kompetisi dalam industri atau sektor bisnis secara lebih baik dibandingkan pesaing

\begin{tabular}{ccccc}
\hline $\begin{array}{c}\text { Alternatif } \\
\text { Jawaban }\end{array}$ & $\begin{array}{c}\text { Alternatif } \\
\text { Skor }\end{array}$ & $\begin{array}{c}\text { Jumlah } \\
\text { Responden } \\
\text { (Orang) }\end{array}$ & $\begin{array}{l}\text { Presentase } \\
\text { Responden }\end{array}$ & Total \\
Skor
\end{tabular}

\begin{tabular}{lllll}
\hline Sangat & 5 & - & - & - \\
Baik & & & - & - \\
Baik & 4 & - & - & - \\
$\begin{array}{l}\text { Cukup } \\
\text { Baik }\end{array}$ & 3 & - & 100 & 26 \\
Tidak & 2 & 13 & - & - \\
Baik & & & & \\
Sangat & 1 & - & $\mathbf{1 0 0}$ & $\mathbf{2 6}$ \\
Tidak & & & \\
Baik & & $\mathbf{1 3}$
\end{tabular}

Hasil penelitian ini menunjukkan bahwa 100 persen responden (13 orang) memilih tidak baik karena UD ini tidak memahami kompetisi dalam industri atau sektor bisnis secara lebih baik dibandingkan pesaing. Yaitu, UD ini tidak memahami kompetisi dalam industri, sehingga UD ini belum melebihi kemampuan para pesaing. Seperti ketekunan dan kurangnya membangun semangat para pekerja (Tabel 11).

\section{Rekapitulasi Orientasi Pasar pada Orientasi Pesaing}

Rekapitulasi adalah ringkasan isi atau ikhtisar pada akhir laporan atau akhir hitungan. Dari hasil perhitungan seluruh variabel pada orientasi pesaing maka ringkasan isi hitungan pada orientasi pasar yaitu sebagai berikut.

Tabel 13 menunjukkan bahwa pernyataan 6 dan 7 memiliki interpretasi baik yaitu pernyataan 6 memiliki indeks orientasi pasar sebesar 63,08 persen dan pernyataan 7 memiliki indeks orientasi pasar sebesar 75,38 persen. Pernyataan 8 memiliki indeks orientasi pasar sebesar 44,61 persen dengan interpretasinya cukup baik. Sedangkan pernyataan 9 dan 10 memiliki indeks orientasi pasar sebesar 40 persen dengan interpretasinya tidak baik. 
Tabel 13. Rekapitulasi pengukuran variabel Orientasi Pesaing pada UD Bintang Lima

\begin{tabular}{llccc}
\hline No & \multicolumn{1}{c}{ PERNYATAAN } & $\begin{array}{c}\text { TOTAL } \\
\text { SKOR }\end{array}$ & $\begin{array}{c}\text { INDEKS } \\
\text { ORIENTASI } \\
\text { PASAR }\end{array}$ & INTERPRETASI \\
\hline $\mathbf{1}$ & $\begin{array}{l}\text { UD Bintang Lima merespon tindakan pesaing secara } \\
\text { lebih cepat dibandingkan para pesaing }\end{array}$ & 41 & 63,08 & Baik \\
$\mathbf{2}$ & $\begin{array}{l}\text { UD Bintang Lima menangkap peluang keunggulan } \\
\text { bersaing secara lebih baik dibandingkan para } \\
\text { pesaing }\end{array}$ & 49 & 75,38 & Baik \\
$\mathbf{3}$ & $\begin{array}{l}\text { UD Bintang Lima bereaksi terhadap strategi/taktik } \\
\text { pesaing secara lebih cepat dibandingkan para } \\
\text { pesaing }\end{array}$ & 29 & 44,61 & Cukup Baik \\
$\mathbf{4}$ & $\begin{array}{l}\text { UD Bintang Lima mampu memprediksi trend } \\
\text { industri atau sektor bisnis secara lebih baik, juga } \\
\text { perusahaan lain yang ingin menjadi agen }\end{array}$ & 26 & 40 & Tidak \\
$\begin{array}{l}\text { UD Bintang Lima memahami kompetisi dalam } \\
\text { industri atau sektor bisnis secara lebih baik } \\
\text { dibandingkan pesaing }\end{array}$ & 26 & 40 & Baik \\
\hline
\end{tabular}

Sumber : Diolah dari data primer 2016

\section{Koordinasi Antar Fungsi}

Koordinasi antar fungsi dalam organisasi perlu dilakukan agar semua sumber daya yang dimiliki perusahaan dapat digunakan secara maksimal untuk menciptakan nilai dan kepuasan konsumen, serta menjaga setiap langkah pesaing yang dapat menghambat strategi-strategi yang sedang di kembangkan oleh perusahaan.

$\underline{\text { Semua pekerja berkontribusi pada strategi UD }}$ Bintang Lima

Strategi merupakan tindakan yang dilakukan berdasarkan sudut pandang tentang apa yang diharapkan oleh para pelanggan dimasa depan. Berkontribusi artinya peran atau keikutsertaan seseorang dalam kegiatan yang direncanakan untuk mencapai tujuan bersama.

Tabel 13 menjelaskan tentang semua pekerja yang berkontribusi pada strategi UD Bintang Lima. Hasil penelitian ini menunjukkan bahwa 23,08 persen responden (3 orang) memilih baik karena pekerja berperan aktif pada strategi UD Bintang Lima. Sedangkan 76,92 persen responden (10 orang) memilih cukup baik karena menurut mereka masih kurang dalam hal keaktifan pekerja dalam UD ini. Pekerja tidak bekerja setiap hari melainkan seminggu hanya dua atau tiga kali.
Tabel 14. Semua pekerja berkontribusi pada strategi UD Bintang Lima

\begin{tabular}{|c|c|c|c|c|}
\hline $\begin{array}{c}\text { Alternatif } \\
\text { Jawaban }\end{array}$ & $\begin{array}{c}\text { Alternatif } \\
\text { Skor }\end{array}$ & $\begin{array}{c}\text { Jumlah } \\
\text { Responden } \\
\text { (Orang) }\end{array}$ & $\begin{array}{l}\text { Presentase } \\
\text { Responden }\end{array}$ & $\begin{array}{l}\text { Total } \\
\text { Skor }\end{array}$ \\
\hline $\begin{array}{l}\text { Sangat } \\
\text { Baik }\end{array}$ & 5 & - & - & - \\
\hline Baik & 4 & 3 & 23,08 & 12 \\
\hline $\begin{array}{l}\text { Cukup } \\
\text { Baik }\end{array}$ & 3 & 10 & 76,92 & 30 \\
\hline $\begin{array}{l}\text { Tidak } \\
\text { Baik }\end{array}$ & 2 & - & - & - \\
\hline $\begin{array}{l}\text { Sangat } \\
\text { Tidak } \\
\text { Baik }\end{array}$ & 1 & - & - & - \\
\hline Total & & 13 & 100 & 42 \\
\hline
\end{tabular}

Sumber : Diolah dari data primer 2016

Informasi tentang pasar

Informasi adalah bahan dasar pengfambilan keputusan dalam kegiatan pemasaran. Dalam bisnis, pasar adalah seluruh masyarakat yang ada disebuah wilayah dgeografis tertentu yang membutuhkan barang atau jasa serta bersedia dan mampu membelinya.

Dalam menjalankan sebuah usaha pada UD ini membutuhkan peralatan dan bahanbahan. Kesemuanya itu merupakan perlengkapan dalam membuat kacang telur. Jadi, informasi tentang pasar sangat penting dalam menjalankan sebuah usaha.

Tabel 15 menjelaskan tentang apakah informasi tentang pasar dibagikan hanya segelintir pekerja. 
Tabel 15. Informasi tentang pasar dibagikan diantara hanya segelintir pekerja

\begin{tabular}{|c|c|c|c|c|}
\hline $\begin{array}{c}\text { Alternatif } \\
\text { Jawaban }\end{array}$ & $\begin{array}{l}\text { Alternatif } \\
\text { Skor }\end{array}$ & $\begin{array}{c}\text { Jumlah } \\
\text { Responden } \\
\text { (Orang) }\end{array}$ & $\begin{array}{l}\text { Presentase } \\
\text { Responden }\end{array}$ & $\begin{array}{l}\text { Total } \\
\text { Skor }\end{array}$ \\
\hline $\begin{array}{l}\text { Sangat } \\
\text { Baik }\end{array}$ & 5 & - & - & - \\
\hline Baik & 4 & - & - & - \\
\hline $\begin{array}{l}\text { Cukup } \\
\text { Baik }\end{array}$ & 3 & 4 & 30,77 & 12 \\
\hline $\begin{array}{l}\text { Tidak } \\
\text { Baik }\end{array}$ & 2 & 9 & 69,23 & 18 \\
\hline $\begin{array}{l}\text { Sangat } \\
\text { Tidak } \\
\text { Baik } \\
\end{array}$ & 1 & - & - & - \\
\hline Total & & 13 & 100 & 30 \\
\hline
\end{tabular}

Sumber : Diolah dari data primer 2016

Hasil penelitian ini menunjukkan bahwa 30,77 persen responden (4 orang) memilih cukup baik, sedangkan 69,23 persen responden (9 orang) memilih tidak baik. Karena menurut UD ini informasi tentang pasar tidak dibagikan hanya sebagian pekerja, melainkan informasi tentang pasar dibagikan kepada pekerja. Seperti harga pada produk kacang telur.

$\underline{\text { Semua pekerja berkontribusi pada penciptaan }}$ nilai pelanggan

Penciptaan nilai adalah penambahan nilai baru terhadap kegiatan individu atau kelompok untuk menghasilkan produk atau jasa yang lebih cepat, lebih tepat, lebih efisien dan lebih bermutu. Tabel 16 menjelaskan tentang apakah semua pekerja berkontribusi pada penciptaan nilai pelanggan.

Tabel 16. Semua pekerja berkontribusi pada penciptaan nilai pelanggan

\begin{tabular}{|c|c|c|c|c|}
\hline $\begin{array}{c}\text { Alternatif } \\
\text { Jawaban }\end{array}$ & $\begin{array}{c}\text { Alternatif } \\
\text { Skor }\end{array}$ & $\begin{array}{c}\text { Jumlah } \\
\text { Responden } \\
\text { (Orang) }\end{array}$ & $\begin{array}{l}\text { Presentase } \\
\text { Responden }\end{array}$ & $\begin{array}{l}\text { Total } \\
\text { Skor }\end{array}$ \\
\hline $\begin{array}{l}\text { Sangat } \\
\text { Baik }\end{array}$ & 5 & - & - & - \\
\hline Baik & 4 & 1 & 7,69 & 4 \\
\hline $\begin{array}{l}\text { Cukup } \\
\text { Baik }\end{array}$ & 3 & 12 & 92,31 & 36 \\
\hline $\begin{array}{l}\text { Tidak } \\
\text { Baik }\end{array}$ & 2 & - & - & - \\
\hline $\begin{array}{l}\text { Sangat } \\
\text { Tidak } \\
\text { Baik }\end{array}$ & 1 & - & - & - \\
\hline Total & & 13 & 100 & 40 \\
\hline
\end{tabular}

Sumber : Diolah dari data primer 2016

Hasil penelitian ini menunjukkan bahwa

7,69 persen responden (1 orang) memilih baik karena pekerja berperan dalam kualitas dan kepuasan pelanggan pada produk ini.
Sedangkan 92,31 persen responden (12 orang) memilih cukup baik karena menurut mereka masih cukupnya para pekerja dalam berperan pada kualitas dan kepuasan para pelanggan. Seperti kurangnya kualitas produk pada dan pemenuhan kebutuhan pelanggan.

Budaya saling bekerja sama antar pekerja dalam UD Bintang Lima

Bekerja sama adalah kerja sama antar perorangan dan antar kelompok manusia untuk mencapai satu atau beberapa tujuan bersama dalam organisasi. Budaya saling bekerja sama antar pekerja sangat penting dalam menjalankan suatu bisnis. Dimana dengan adanya kerjasama dalam bisnis tersebut, maka apa yang diinginkan dalam perusahaan dapat tercapai.

Dalam melakukan suatu pekerjaan tentunya ada saling kerja sama antar pekerja dan pimpinannya dilihat dari sifat dan sikap . Karena tanpa adanya saling kerja sama, apa yang diharapkan dalam usaha yang kita jalani tidak dapat berjalan dengan baik.

Tabel 17 menjelaskan tentang budaya saling bekerja sama antar pekerja dalam UD Bintang Lima.

Tabel 17. Adanya Budaya saling kerja sama antar pekerja dalam UD Bintang Lima

\begin{tabular}{lcccc}
\hline $\begin{array}{l}\text { Alternatif } \\
\text { Jawaban }\end{array}$ & $\begin{array}{c}\text { Alternatif } \\
\text { Skor }\end{array}$ & $\begin{array}{c}\text { Jumlah } \\
\text { Responden } \\
\text { (Orang) }\end{array}$ & $\begin{array}{c}\text { Presentase } \\
\text { Responden }\end{array}$ & $\begin{array}{c}\text { Total } \\
\text { Skor }\end{array}$ \\
\hline $\begin{array}{l}\text { Sangat } \\
\text { Baik }\end{array}$ & 5 & 9 & 69,23 & 45 \\
Baik & 4 & 4 & 30,77 & 16 \\
Cukup & 3 & - & - & - \\
Baik & 2 & - & - & - \\
Tidak & 1 & - & - & - \\
Baik & & & $\mathbf{1 0 0}$ & $\mathbf{6 1}$ \\
Sangat & & $\mathbf{1 3}$ & \\
Tidak & & & & \\
Baik & & & & \\
\hline Total & & & &
\end{tabular}

Hasil penelitian ini menunjukkan bahwa 69,23 persen responden ( 9 orang) memilih sangat baik, sedangkan 30,77 persen responden (4 orang) memilih baik karena dalam UD ini memiliki budaya saling kerja sama antar pekerja, yaitu dengan adanya kebersamaan, saling menghormati dan menghargai antara satu dengan yang lain. 
Staf pemasaran UD Bintang Lima jarang berinteraksi dengan pekerja lainnya

Staf pemasaran merupakan jabatan yang bergera di bidang penjualan perusahaan, memiliki tugas utama melakukan penjualan produk perusahaan dalam rangka pencapaian target perusahaan.

Dalam suatu pekerjaan kebersamaan karyawan sangat diinginkan oleh pimpinannya. Dimana diharapkan para karyawan dapat berinteraksi dengan pekerja lainnya atau kontak pelanggan antar fungsi.

Tabel 18 menjelaskan tentang apakah staf pemasaran pada UD ini jarang berinteraksi dengan pekerja lainnya.

Tabel 18. Staf pemasaran UD Bintang Lima jarang berinteraksi dengan pekerja lainnya

\begin{tabular}{lcccc}
\hline $\begin{array}{l}\text { Alternatif } \\
\text { Jawaban }\end{array}$ & $\begin{array}{c}\text { Alternatif } \\
\text { Skor }\end{array}$ & $\begin{array}{c}\text { Jumlah } \\
\text { Responden } \\
\text { (Orang) }\end{array}$ & $\begin{array}{c}\text { Presentase } \\
\text { Responden }\end{array}$ & $\begin{array}{c}\text { Total } \\
\text { Skor }\end{array}$ \\
\hline Sangat & 5 & - & - & - \\
Baik & 4 & - & - & - \\
Baik & 3 & 13 & 100 & 39 \\
Cukup & 2 & - & - & - \\
Baik & 1 & - & - & - \\
Tidak & & & & \\
Baik & & & $\mathbf{1 0 0}$ & $\mathbf{3 9}$ \\
Sangat & Tidak & & $\mathbf{1 3}$ & \\
Baik & & & & \\
\hline Total & & & & \\
\hline Sumber $:$ Diolah daridata primer 2016
\end{tabular}

Sumber : Diolah dari data primer 2016

Hasil penelitian ini menunjukkan bahwa 100 persen responden (13 orang) memilih cukup baik karena sebagian staf pemasaran jarang berinteraksi dengan pekerja lainya. Hal ini terjadi karena mereka sibuk akan pekerjaan mereka masing-masing. Seperti komunikasi antar staf pemasaran dengan pekerja lainnya.

\section{Rekapitulasi Orientasi Pasar pada Koordinasi} Antar Fungsi

Rekapitulasi adalah ringkasan isi atau ikhtisar pada akhir laporan atau akhir hitungan. Dari hasil perhitungan seluruh variabel pada koordinasi antar fungsi maka rekapitulasinya sebagai berikut.

Tabel 19 menunjukkan bahwa pernyataan nilai 11,13 memiliki interpretasi baik yaitu, pernyataan 11 memiliki indeks orientasi pasar sebesar 64,61 persen, pernyataan 13 memiliki indeks orientasi pasar sebesar 61,54 persen. Pernyataan 14, memiki indeks orientasi pasar sebesar 93,84 persen dengan memiliki interpretasi sangat baik. Sedangkan pernyataan 12 dan 15 memiliki interpretasi cukup baik yaitu pernyataan 12 indeks orientasi pasar sebesar 46,15 persen, pernyataan 15 , memiliki indeks orientasi pasar sebesar 60 persen.

Tabel 19. Rekapitulasi pengukuran variabel Koordinasi Antar Fungsi pada UD Bintang Lima

\begin{tabular}{|c|c|c|c|c|}
\hline No & PERNYATAAN & $\begin{array}{l}\text { TOTAL } \\
\text { SKOR }\end{array}$ & $\begin{array}{c}\text { INDEKS } \\
\text { ORIENTAS } \\
\text { I PASAR }\end{array}$ & $\begin{array}{c}\text { INTER- } \\
\text { PRETASI }\end{array}$ \\
\hline 1 & $\begin{array}{l}\text { Semua pekerja } \\
\text { berkontribusi pada } \\
\text { strategi UD } \\
\text { Bintang Lima }\end{array}$ & 42 & 64,61 & Baik \\
\hline 2 & $\begin{array}{l}\text { Informasi tentang } \\
\text { pasar dibagikan } \\
\text { diantara hanya } \\
\text { segelintir pekerja }\end{array}$ & 30 & 46,15 & $\begin{array}{c}\text { Cukup } \\
\text { Baik }\end{array}$ \\
\hline 3 & $\begin{array}{l}\text { Semua pekerja } \\
\text { berkontribusi pada } \\
\text { penciptaan nilai } \\
\text { pelanggan }\end{array}$ & 40 & 61,54 & Baik \\
\hline 4 & $\begin{array}{l}\text { Adanya budaya } \\
\text { saling bekerja } \\
\text { sama antar pekerja } \\
\text { dalam UD Bintang } \\
\text { Lima }\end{array}$ & 61 & 93,84 & $\begin{array}{c}\text { Sangat } \\
\text { Baik }\end{array}$ \\
\hline 5 & $\begin{array}{l}\text { Staf pemasaran UD } \\
\text { Bintang Lima } \\
\text { jarang berinteraksi } \\
\text { dengan pekerja } \\
\text { lainnya }\end{array}$ & 39 & 60 & $\begin{array}{l}\text { Cukup } \\
\text { Baik }\end{array}$ \\
\hline
\end{tabular}

Rekapitulasi Orientasi Pasar dalam UD Bintang Lima pada masing-masing orientasi

Penelitian ini untuk mengukur Orientasi Pasar dengan mengambil 15 pernyataan, dimana masing- terbagi dalam 3 (tiga) bagian yaitu orientasi pelanggan, orientasi pesaing dan koordinasi antar fungsi. Tabel 19 menunjukkan dari 15 pernyataan, terdapat 3 pernyataan yang memiliki nilai interpretasi sangat baik (80-100 $\%$ ), yaitu pernyataan 4, 5 dan 14. Terdapat 6 pernyataan yang memiliki nilai interpetasi yang baik (60-80\%), yaitu pernyataan $1,2,6,7,11$, 13. Terdapat 4 pernyataan yang memiliki nilai interpretasi cukup baik (40-60\%), yaitu pernyataan 3, 8,12 dan 15 . Dan terdapat 2 pernyataan yang memiliki nilai interpretasi tidak baik (20-40\%), yaitu pernyataan 9 dan 10 . 
Tabel 20. Rekapitulasi Total Skor, Indeks dan Interpretasi Hasil

\begin{tabular}{|c|c|c|c|c|}
\hline No & PERNYATAAN & $\begin{array}{l}\text { TOTAL } \\
\text { SKOR }\end{array}$ & $\begin{array}{l}\text { INDEKS } \\
\text { ORIENTASI } \\
\text { PASAR }\end{array}$ & $\begin{array}{l}\text { INTERP } \\
\text { RETASI }\end{array}$ \\
\hline $\mathbf{1}$ & $\begin{array}{l}\text { UD Bintang Lima memahami kebutuhan } \\
\text { pelanggan secara lebih baik dibandingkan para } \\
\text { pesaing }\end{array}$ & 52 & 80 & Baik \\
\hline 2 & $\begin{array}{l}\text { UD Bintang Lima menciptakan nilai bagi } \\
\text { pelanggan secara lebih baik dibandingkan para } \\
\text { pesaing }\end{array}$ & 50 & 76,92 & Baik \\
\hline 3 & $\begin{array}{l}\text { UD Bintang Lima kurang berfokus pada } \\
\text { komitmen pelanggan dibandingkan para pesaing }\end{array}$ & 30 & 46,15 & $\begin{array}{l}\text { Cukup } \\
\text { Baik }\end{array}$ \\
\hline 4 & $\begin{array}{l}\text { UD Bintang Lima kurang memperhatikan } \\
\text { kepuasan pelanggan dindingkan para pesaing }\end{array}$ & 59 & 90,76 & $\begin{array}{l}\text { Sangat } \\
\text { Baik }\end{array}$ \\
\hline 5 & $\begin{array}{l}\text { UD Bintang Lima merespon tuntutan kebutuhan } \\
\text { pelanggan secara lebih efektif dibandingkan para } \\
\text { pesaing }\end{array}$ & 53 & 81,53 & $\begin{array}{l}\text { Sangat } \\
\text { Baik }\end{array}$ \\
\hline 6 & $\begin{array}{l}\text { UD Bintang Lima merespon tindakan pesaing } \\
\text { secara lebih cepat dibandingkan para pesaing }\end{array}$ & 41 & 63,08 & Baik \\
\hline 7 & $\begin{array}{l}\text { UD Bintang Lima menangkap peluang } \\
\text { keunggulan bersaing secara lebih baik } \\
\text { dibandingkan para pesaing }\end{array}$ & 49 & 75,38 & Baik \\
\hline 8 & $\begin{array}{l}\text { UD Bintang Lima bereaksi terhadap } \\
\text { strategi/taktik pesaing secara lebih cepat } \\
\text { dibandingkan para pesaing }\end{array}$ & 29 & 44,61 & $\begin{array}{l}\text { Cukup } \\
\text { Baik }\end{array}$ \\
\hline 9 & $\begin{array}{l}\text { UD Bintang Lima mampu memprediksi trend } \\
\text { industri atau sektor bisnis secara lebih baik, juga } \\
\text { perusahaan lain yang ingin menjadi agen }\end{array}$ & 26 & 40 & $\begin{array}{l}\text { Tidak } \\
\text { Baik }\end{array}$ \\
\hline $\mathbf{1 0}$ & $\begin{array}{l}\text { UD Bintang Lima memahami kompetisi dalam } \\
\text { industri atau sektor bisnis secara lebih baik } \\
\text { dibandingkan pesaing }\end{array}$ & 26 & 40 & $\begin{array}{l}\text { Tidak } \\
\text { Baik }\end{array}$ \\
\hline 11 & $\begin{array}{l}\text { Semua pekerja berkontribusi pada strategi UD } \\
\text { Bintang Lima }\end{array}$ & 42 & 64,61 & Baik \\
\hline 12 & $\begin{array}{l}\text { Informasi tentang pasar dibagikan diantara hanya } \\
\text { segelintir pekerja }\end{array}$ & 30 & 46,15 & $\begin{array}{l}\text { Cukup } \\
\text { Baik }\end{array}$ \\
\hline 13 & $\begin{array}{l}\text { Semua pekerja berkontribusi pada penciptaan } \\
\text { nilai pelanggan }\end{array}$ & 40 & 61,54 & Baik \\
\hline 14 & $\begin{array}{l}\text { Adanya budaya saling bekerja sama antar pekerja } \\
\text { dalam UD Bintang Lima }\end{array}$ & 61 & 93,84 & $\begin{array}{l}\text { Sangat } \\
\text { Baik }\end{array}$ \\
\hline 15 & $\begin{array}{l}\text { Staf pemasaran UD Bintang Lima jarang } \\
\text { berinteraksi dengan pekerja lainnya }\end{array}$ & 39 & 60 & $\begin{array}{c}\text { Cukup } \\
\text { Baik }\end{array}$ \\
\hline
\end{tabular}

Sumber : Diolah dari data primer, 2016

Untuk mengetahui letak Orientasi Paar paa UD Bintang Lima, maka perlu dihitung jumlah keseluruhan skor pada setiap pernyataan, dimana sesuai hasil penelitian ini skor mencapai 627. Pada penelitian ini, jumlah skor ideal (skor tertinggi), yaitu 975 (tinggi) dan jumlah skor terendah yaitu 195 (rendah). Berdasarkan data yang dihimpun dari sebanyak 15 pernyataan yang diajukan kepada kepada 13 orang responden, maka diperoleh total skor 645 . Secara persentase, angka indeks Orientasi Pasar pada UD Bintang Lima terletak pada

\section{Orientasi Pasar}

Jumlah skor hasil pengumpulan data $=\frac{\text { Jumlah skor ideal (tertinggi) }}{\text { Jum }} 100 \%$

$$
=\frac{627}{975} x 100 \%=64,31 \%
$$

Berdasarkan hasil analisis menggunakan skala Likert, maka dapat diketahui bahwa angka Orientasi Pasar pada UD Bintang Lima berada diantara angka 60 persen dan angka 80 persen, sehingga tergolong Baik. 


\section{KESIMPULAN DAN SARAN}

\section{KESIMPULAN}

Penelitian ini menunjukkan bahwa UD Bintang Lima telah menangkap orientasi pasar yaitu Baik. Orientasi pasar pada UD ini dikatakan baik dalam orientasi pelanggan yaitu pemahaman UD ini terhadap keinginan pelanggan, mengetahui apa yang diinginkan pelanggan, kepuasan serta menciptakan nilai bagi pelanggan. Dalam orientasi pesaing, UD ini merespon tindakan pesaing, menangkap peluang keunggulan bersaing, dan berusaha meningkatkan dan menemukan strategi untuk melawan pesaingnya. Sedangkan dalam koordinasi antar fungsi, para pekerja berkontribusi pada strategi UD Bintang Lima dan pada penciptaan nilai pelanggan, saling bekerjasama antar pekerja, dan untuk memahami kebutuhan pelanggan sehingga tercipta kepuasan bagi pelanggannya.

\section{SARAN}

Berdasarkan perolehan hasil data, UD Bintang Lima memiliki Orientasi Pasar yang Baik, maka disarankan agar pekerja tetap mempertahankan dan meningkatkan dalam terbentuknya Orientasi Pasar yaitu pada orientasi pelanggan, orientasi pesaing dan koordinasi antar fungsi.

\section{DAFTAR PUSTAKA}

Adinoto., 2012, Pengaruh Orientasi Pasar dan Perilaku Kewiausahaan Terhadap Kepekaan Perusahaan dan Impikasinya pada Kinerja Perusahaan: Studi pada Penyalur Sepeda Motor di Indonesia, Ultima Management, Vol 4, No.10.

Alam, M.M., 2013, Effect of Market Orientation on Small Business Performance in Small Town In Malayia: An Emprical Study on Malaysian Small Firms, Journal of Strategic Marketing, Vol.1, No.3.

Cano, C.R., 2004, “ A Meta-analysis of the Relationship Between Market Orientation and Business Performance: Evidence from five continents", International Journal of Research in Marketing, Vol. 21, pp. 179-200.
Craven, D.W., 1994, Pemasaran Strategis. Penerbit : Erlangga, Jakarta.

Ferdinand, A., 2000, Manajemen Pemasaran : sebuah Pendekatan Stratejik, Journal of Research Paper Series, Vol. 1, No.1.

Harris, L. C, 2003, “ Measuring Market Orientation: Exploring a Market Oriented Approach ", Journal of Market Focused Management, Vol. 5, pp. 239-270.

Kirca, A. H, 2005, “ Market Orientation: A Meta-analytic Review and Assessment of its Antecedents and Impact on Performance ", Journal of Marketing, Vol. 69 (April), pp.24-41.

Kotler, P., 2002, Manajemen Pemasaran, jilid 1, Edisi Milenium, Jakarta, Prehallindo.

Kotler, P. 2007, Manajemen Pemasaran, Anaisis, Perencanaan, Implmentasi dan Pengendalian, penerbit: Erlangga, Jakarta.

Lamb, C.W. 2001, Pemasaran, Penerbit : Salemba Empat, Jakarta.

Mangkunegara, A.A.A.P , 2001, Perilaku Konsumen, penerbit : Refika Aditama, Bandung.

Narver, J. C., Slater, S.F., 1990, The Effect of a Market Orientation on Business Profitability, Journal of Marketing, Vol. 54, No. 10.

Narver, J. C., Slater, S. F., 1994, Creating a Market Orientation, Journal of MarketFocused Management, Vol.2, No 3.

Pramono, S. dan Waridin. 2006, Pengaruh Faktor Orientasi Pasar, Promosi dan Inovasi terhadap kinerja Pemasaran Kredit ( studi kasus pada Bank BRI wilayah Jawa Tengah), Ekobs, Vol.7, No.1, Januari, 33-40.

Riduwan, 2012, Rumus dan data dalam Analisis Statistika. Penerbit Alphabet, Bandung.

Sedarmayanti,. 2010, Manajemn Sumber Daya Manausia Reormasi Birokrasi dan Manajemen Pegawai Negeri Sipil. Bandung : PT Refika Aditama.

Wiyono., 2013, Analisis Anteseden Orientasi Pasar dan Pengaruhnya terhadap Pembelajaran Organisasi Umkm di Eks Karesidenan Surakart, Semnas Fekon : Optimisme Ekonomi Indnesia 2013, Antara Peluang dan Tantangan. 
Wulandari A., 2013, Pengaruh Orientasi Pelanggan, Orientasi Pesaing dan Inovasi Produk Terhadap Kinerja Pemasaran, Management Analysis Journal, Vol.1, No.2.
Zhou K., 2005, The Effect of Strategic Orientations on Technology- and Market - Based Breakthrough Innovations. Journal of Marketing. Vol. 69. 